\title{
The Russian Old-Settlers in the Arctic Coast of Eastern Siberia: Family Name Diversity in the Context of Their Origin
}

\author{
Aisen V. Solovyev ${ }^{1,2}$, Tuyara V. Borisova ${ }^{2}$, Aleksandra M. Cherdonova ${ }^{2}$, Georgii P. Romanov ${ }^{2}(\mathbb{D}$, \\ Fedor M. Teryutin ${ }^{3}$, Vera G. Pshennikova ${ }^{3}$, Nyurgun N. Gotovtsev ${ }^{3}$, Olga V. Vasileva ${ }^{1}$, Sargylana E. Nikitina ${ }^{1}{ }^{1}$, \\ Nikolay A. Barashkov ${ }^{3, *(D)}$, Anatoly N. Alekseev ${ }^{1,2} \mathbb{D}$ and Sardana A. Fedorova ${ }^{2}$ D \\ 1 Institute for Humanities Research and Indigenous Studies of the North, Siberian Branch of the Russian \\ Academy of Sciences, Petrovskogo 1, 677007 Yakutsk, Russia; nelloann@mail.ru (A.V.S.); \\ osipovaovr@rambler.ru (O.V.V.); sarg_nik.ykt@mail.ru (S.E.N.); alekan46@mail.ru (A.N.A.) \\ 2 Laboratory of Molecular Biology, M.K. Ammosov North-Eastern Federal University, Kulakovskogo 46 , \\ 677010 Yakutsk, Russia; borisovatv96@gmail.com (T.V.B.); cherdonovasasha96@gmail.com (A.M.C.); \\ gpromanov@gmail.com (G.P.R.); sardaanafedorova@mail.ru (S.A.F.) \\ 3 Yakut Science Centre of Complex Medical Problems, Yaroslavskogo 6/3, 677000 Yakutsk, Russia; \\ rest26@mail.ru (F.M.T.); psennikovavera@mail.ru (V.G.P.); donzcrew@mail.ru (N.N.G.) \\ * Correspondence: barashkov2004@mail.ru
}

Citation: Solovyev, A.V.; Borisova, T.V.; Cherdonova, A.M.; Romanov, G.P.; Teryutin, F.M.; Pshennikova, V.G.; Gotovtsev, N.N.; Vasileva, O.V.; Nikitina, S.E.; Barashkov, N.A.; et al. The Russian Old-Settlers in the Arctic Coast of Eastern Siberia: Family Name Diversity in the Context of Their Origin. Sustainability 2021, 13, 10895. https://doi.org/10.3390/ su131910895

Academic Editor: Ioannis Liritzis

Received: 18 August 2021

Accepted: 28 September 2021

Published: 30 September 2021

Publisher's Note: MDPI stays neutral with regard to jurisdictional claims in published maps and institutional affiliations.

Copyright: (c) 2021 by the authors. Licensee MDPI, Basel, Switzerland. This article is an open access article distributed under the terms and conditions of the Creative Commons Attribution (CC BY) license (https:/ / creativecommons.org/licenses/by/ $4.0 /)$.
Abstract: The populations of the Arctic Ocean coast in Eastern Siberia (Russia) are represented by a multicultural conglomerate of peoples of different origins: Paleo-Asiatic (Chukchi), Uralic (Yukaghirs), Tungusic (Evenks, Evens), Turkic (Yakuts, Dolgans), and Slavic (Russian explorers), who inhabited this territory during various historical periods. However, among the modern Arctic populations there are still "white spots", such as people of the small village of "Russkoe Ust'ye", who still have not been thoroughly studied. The main population consists of so called Russian old-settlers-the Russkoustinians. They traditionally distinguish their lineages into three groups identified by their time of settlement. First are the "Pomors" - who according to their legends are considered as the descendants of the first European colonists of the Age of Discovery, who settled the eastern shores of the Arctic Ocean in the 16th century before the inclusion of this territory in the Russian Empire in the early 17th century. Second are the "Cossacks" - who reached the Arctic during explorations of Siberia. The last are the "Zashiversk" - who arrived after the abolition of their hometown. In order to test these hypotheses, we analyzed modern family name diversity based on information on 62 individuals from 36 questionnaires. The analysis revealed that the "Pomors" lineages were presented in five families (43.5\%), the "Cossacks" in one family (6.5\%), and the "Zashiversk" in $37.1 \%$ of families. This fact indicates a probability that this village was founded by Russian Pomors who arrived there by the Northern Sea Routes before the official East Siberian colonization period.

Keywords: Russian old-settlers; indigenous people; family names; Russkoe Ust'ye; Arctic Ocean; Eastern Siberia; Sakha Republic; Russia

\section{Introduction}

At different historical times, the Arctic landscape was successfully inhabited by humans who managed to survive and adapt to the harsh climate and who brought new types of farming (reindeer and northern cattle breeding) to this area. The Arctic Ocean coast populations of Eastern Siberia (Russia) represent a multicultural conglomerate of people of different origins: Paleo-Asiatic (Chukchi), Uralic (Yukaghirs), Tungusic (Evenks, Evens), Turkic (Yakuts, Dolgans), and Slavic (Russian explorers of Siberia and Arctic), who inhabited this territory during various historical periods. However, among the modern Arctic populations there are still "white spots", such as people of the small village named Russkoe Ust'ye, which still have not been thoroughly studied. The main population consists of so called Russian old-settlers-the Russkoustinians. They are a sub-population of 
Russian origin, who are probably descendants of the first European colonists of the Age of Discovery who settled the Arctic Ocean shores of Eastern Siberia in the 16th century, long before the inclusion of this territory in the Russian Empire in the early 17th century.

The Russians of the Arctic did not keep cattle or engage in reindeer herding, unlike the neighboring nomadic tribes of the Yukaghirs, Evenks, and Chukchi. The main occupations of the Russian old-settlers for four centuries was fishing and polar fox hunting. They also were the first to introduce the use of seine nets for river fishing, which was a technique later adopted by neighboring local peoples. The geographical isolation due to long distances and the short seasonal availability of river transport was the reason why local indigenous tribes were almost the only possible "neighbors" of the Russian old-settlers [1]. Generations of such neighborhoods, led to the formation of a special Russkoustinian subpopulation. Russkoustinians have their own unique culture and have preserved a very specific dialect of the Russian language. Nevertheless, as pointed out in the literature, for a long time the Russian old-settler groups were absent from the sphere of attention of the government and the field of interest for researchers; they were neither "newcomers" or "indigenous peoples" [2]. At present, the inhabitants of Russkoe Ust'ye are the subject of research by historians, anthropologists, and folklorists, but despite this, due to the intermediate position that they occupy, certain collisions are created in relation to the governmental policy of institutionalizing ethnicity [2].

Currently, the total population of the Russian Federation is 146 million people, and 111 million of them are Russians, while the other 35 million people are represented by other different ethnicities and ethnic groups (179 different ethnicities) [3]. Among them, 40 ethnic groups have been given a special status as indigenous minority peoples [4]. This status was introduced in order to protect the traditional lifestyle of indigenous minority peoples of Russia living in the North, Siberia, and the Far East of Russia. Indigenous peoples have been subject to legal regulations for a long time. The status of indigenous minorities provides special assistance and certain benefits from the government such as: an exemption of fees in places of traditional residence; tuition free higher education; exemption from military service; support for the use of native languages, as well as special rights to the use of wildlife; benefits for land use and nature management; and the opportunity to preserve traditional economic practices in the territories of their ancestors' traditional settlement in the event of industrial development [4]. In the design of the list of indigenous minority peoples of the North, according to some anthropologists there is an inconsistency and political conjuncture, expressed in relation to the recognition of mestizo or highly mestizo groups, traditionally classified either as indigenous peoples or the Russian old-settlers. Thus, the Kamchadals received the status of a separate people and are now counted independently of the Itelmens and the Russians, although they were previously considered as an old-time group of Russians, and the Russkoe Ust'ye still have not received this status. However, since people of the Russkoe Ust'ye are still officially considered as Russians, the identified government benefits and assistance are not available to them at present. One of the possible ways for Russkoustinians to obtain the status of an indigenous minority people of the North is to define their history and origin.

Among many interesting features, people of the Russkoe Ust'ye traditionally divide their lineages and family names into two groups: early settlers who are referred to in Russian as "doselnye" or "Pomor" (rus.—seaman), and late settlers referred to as "prishlie" (rus.-newcomers). The reason for this division was the migrations which were caused by the active industrial development of the North. As a result, it became possible for the local populations to make contact with newcomers, who then became known as the "prishlie" [5]. Family names can be successfully used as quasi-genetic markers when studying population structures, which was shown in Crow, 1983; Balanovskaya et al., 2005; and Balanovskaya et al., 2011 [6-8]. In this regard, the study of the diversity of family names of the Russian old-settlers can serve as an additional tool in the study of their origins. The aim of this study is the investigation of family name diversity of the Russian old-settlers living in the Arctic coast of Eastern Siberia in the context of their origins. 


\section{Materials and Methods}

\subsection{Geographical Location of the Russkoe Ust'ye}

Russkoe Ust'ye is a small village in the middle of the tundra in Northeast Siberia, Russia $\left(71^{\circ} 08^{\prime} 02.2^{\prime \prime} \mathrm{N}, 149^{\circ} 16^{\prime} 17.4^{\prime \prime} \mathrm{E}\right)$. It is located upon the lower Indigirka river on the Arctic Ocean shore in the Allaikhovsky region of the Republic of Sakha (Yakutia). According to official statistics, currently the total population of the Russkoe Ust'ye is 128 people. In the village, people are occupied in the school, kindergarten, the medical office, administration, the power and heating station and in small shops. Life in Russkoe Ust'ye is focused on and driven by seasonal fishing and hunting. Each family has a plot of land away from the village called a zaimka, which they traditionally occupy and use for fishing, hunting and the preparation of supplies for long winters. Therefore, it is difficult to find the majority people within the village itself during warmer periods of the year when river transport to Russkoe Ust'ye is available. During the long winter, the unpredictable local climate accompanied with the large distances between settlements leaves very few possibilities for transportation which requires special all-terrain vehicles or snowmobiles.

\subsection{Early Studies about Russkoe Ust'ye}

Earlier studies of Russkoe Ust'ye have been concerned with the culture [9,10], folklore [11-13], the unique dialect [10,14-17], the way of life in Russkoe Ust'ye [1,16,18-23], history $[5,16,20,24-26]$, hypotheses of origins [16,25,27-30], ethnical components [23,31,32], anthropology [33], ethno-markers [2], and a genetic study [34].

\subsection{Methodology of Family Name Diversity}

Family names can be used as quasi-genetic markers [6] and may represent a selectiveneutral marker because their effect on mortality and fertility is unlikely [35]. Thus, family names can be extremely informative in studies of ancestry, admixture and migrations [35]. The transmission of family names in a series of generations through the paternal line is characteristic of many ethnic groups, so this marker describes only the male portion of the gene pool [36], which distinguishes it from true genetic markers [35]. The high informative opportunities of this method for describing the structure of populations have been confirmed by many studies [7,37-39]. The first Russian family names, according to the 13th century chronicles, were the inhabitants of Novgorod and throughout the 14 and 15th centuries princely and boyar (rus.- - title) family names emerged, while during the 13th to 19th centuries merchant family names emerged, and from the middle of the 13th century clerical family names emerged [40]. In Eastern Siberia, in the documents of 1748, among the Russian population some Russkoustinian family names are listed, such as the Cheremkins, the Shkulevs and the Suzdalovs, all mentioned as residents of the Zashiversk ostrog, and the Portnyagins as residents of Ust-Yansk [41]. According to previously published information in the essay of native Russkoustinian Aleksey Chikachev [16], the modern lineages of the Russkoe Ust'ye are divided into three major groups of colonizers (Figure 1). The first group named as the "Pomors" are represented by 6 lineages (Shelokhovskiy, Strukov, Suzdalov, Shkulev, Chikachev and Cheremkin). The second group, the "Cossacks" is represented by one clan (Kiselev). The third group "Zashiversk" is represented by 10 lineages (Shakhov, Shulgin, Banshikov, Soldatov, Portniagin, Titov, Efimov, Malishev, Chistov and Omelchenko) [16]. The first two groups (Pomors and Cossacks) are considered as early settlers, the third one as late settlers.

\subsection{Sample}

During the last comprehensive expeditions to the Arctic regions of the Republic of Sakha in 2018-2019, a population of Russkoe Ust'ye was studied. After the acquisition of full informed consent, volunteers answered a questionnaire aimed at defining their maternal and paternal lineages which included the composition of genealogical trees as well as the reporting of known facts about their history of origin. A total of 36 questionnaires were completed with information relating to 62 individuals. 


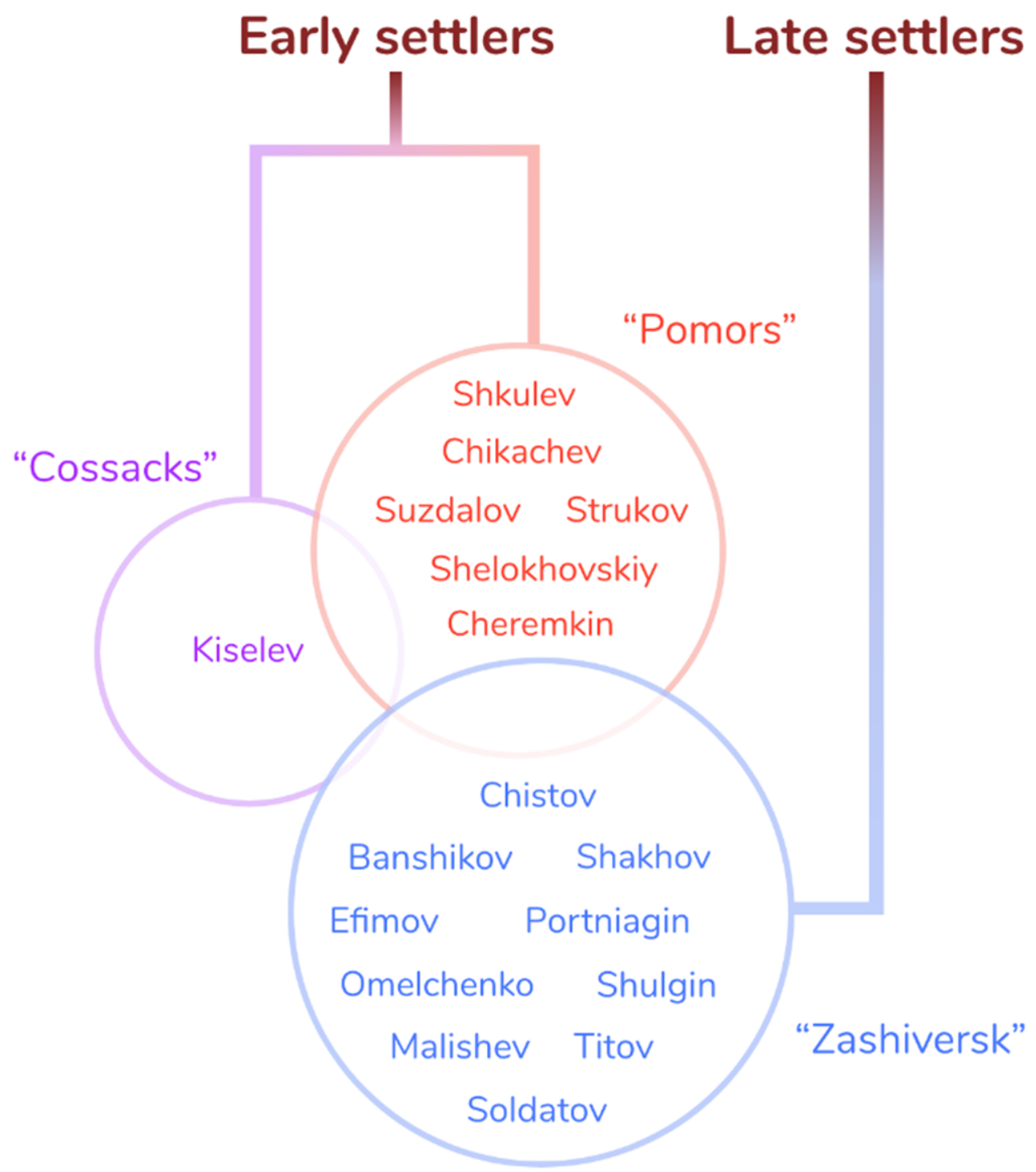

Figure 1. Family name diversity of the Russian old-settlers of the Arctic coast of Eastern Siberia by Chikachev [16].

\subsection{Ethical Approval}

This study was approved by the local biomedical ethics committee of the Yakut Science Centre of Complex Medical Problems, Yakutsk, Russia (Protocol No.4, 1 March 2018).

\section{Results}

\subsection{Analysis of Family Name Diversity}

Based on the results of questionnaire analysis, a sample of 62 people was formed, which amounted to $48.4 \%$ of the total number of the residents in the village of Russkoe Ust'ye. The sample comprised of 20 males (32\%) and 42 females (68\%). In this sample there were 13 native Russkoustinian family names out of a reported 17 (Figure 1) [16]. There were also eight newcomer family names (12.9\%) that are not mentioned in the old records of Russkoe Ust'ye. The five native lineages out of 13 were the most common, with the proportion of carriers of these lineages ranging from $11.3 \%$ to $14.5 \%$, accounting for $64.5 \%$ of the total sample (Table 1$)$. The remaining lineages (35.5\%) included 16 less common lineages, eight of which are new ones $(12.9 \%)$ (Table 1$)$. Thus, in the studied sample the carriers of Russkoustinian family names prevailed (87.1\%). 
Table 1. Diversity of family names in the residents of Russkoe Ust'ye.

\begin{tabular}{|c|c|c|c|c|c|c|}
\hline$\#$ & $\begin{array}{l}\text { Family } \\
\text { Names }\end{array}$ & $\begin{array}{c}\text { Male } \\
(n)\end{array}$ & $\begin{array}{l}\text { Female } \\
(n)\end{array}$ & $\begin{array}{c}\text { Total } \\
(n)\end{array}$ & $\%$ & $\begin{array}{l}\text { Native/Newcomer } \\
\text { Family Names }\end{array}$ \\
\hline 1 & Efimov & 3 & 6 & 9 & $14.5 \%$ & \multirow{13}{*}{$\begin{array}{l}\text { Native family names } \\
\qquad(87.1 \%)\end{array}$} \\
\hline 2 & Cheremkin & 4 & 4 & 8 & $12.9 \%$ & \\
\hline 3 & Chikachev & 2 & 6 & 8 & $12.9 \%$ & \\
\hline 4 & Portniagin & 3 & 5 & 8 & $12.9 \%$ & \\
\hline 5 & Shkulev & 3 & 4 & 7 & $11.3 \%$ & \\
\hline 6 & Kiselev & 2 & 2 & 4 & $6.5 \%$ & \\
\hline 7 & Suzdalov & - & 3 & 3 & $4.8 \%$ & \\
\hline 8 & Shakhov & - & 2 & 2 & $3.2 \%$ & \\
\hline 9 & Malishev & 1 & - & 1 & $1.6 \%$ & \\
\hline 10 & Omelchenko & - & 1 & 1 & $1.6 \%$ & \\
\hline 11 & Shelokhovskiy & 1 & - & 1 & $1.6 \%$ & \\
\hline 12 & Shulgin & - & 1 & 1 & $1.6 \%$ & \\
\hline 13 & Soldatov & - & 1 & 1 & $1.6 \%$ & \\
\hline 14 & Antonen & - & 1 & 1 & $1.6 \%$ & \multirow{8}{*}{$\begin{array}{l}\text { Newcomer family names } \\
\qquad(12.9 \%)\end{array}$} \\
\hline 15 & Kolyasnikova & - & 1 & 1 & $1.6 \%$ & \\
\hline 16 & Zueva & - & 1 & 1 & $1.6 \%$ & \\
\hline 17 & Myasoedova & - & 1 & 1 & $1.6 \%$ & \\
\hline 18 & Prokopyeva & - & 1 & 1 & $1.6 \%$ & \\
\hline 19 & Chernetskis & - & 1 & 1 & $1.6 \%$ & \\
\hline 20 & Yusupova & - & 1 & 1 & $1.6 \%$ & \\
\hline 21 & Shyshmarev & 1 & - & 1 & $1.6 \%$ & \\
\hline \multicolumn{2}{|c|}{ Total $=n(\%)$} & $\begin{array}{c}20 \\
(32 \%)\end{array}$ & $\begin{array}{c}42 \\
(68 \%)\end{array}$ & \multicolumn{3}{|c|}{$62(100 \%)$} \\
\hline
\end{tabular}

Note: $n$-number of persons; the text in bold indicates the most common family names $(>10 \%)$.

\subsection{Etymological and Onomastic Features of the Most Common Family Names in Russkoe Ust'ye}

The family name Efimov originated from the name Euphemius, which appeared after the Baptism of Russia. The suffix -ov, which is part of the family name, is a patronymic particle of Great Russian origin and denotes the origin of the patronymic Efimov in the territory of Russia, when among wealthy people it began to create and pass on, from generation to generation, family names that denoted a person's belonging to a particular family. Also, the family name Efimov could be attached to the representatives of the family after the abolition of serfdom in Russia. Many peasants did not have family names and were recorded in documents by the family name of their landlord or by the name of their locality, i.e., the village where they lived [42-45]. We have not found sufficiently reliable sources about the origin of the family name Cheremkin, so we can only cite data on the family name ending. Historically, the average ratio of family names in Russian populations with -ov/iev/-yov to family names with -in/-yin may be stated as $70 \%$ to $30 \%$. In some regions of Russia, especially in the Volga region, family names that end on -in/yin comprise more than $50 \%$ of the population [46]. In ancient records, citizens with the family name Chikachev belonged to the high society of the Russian Kiev clergy in the 18th and 19th centuries, who held a certain power and honor. The original mention of the family name can be gleaned from the table of inhabitants of ancient Russia during the reign of Ivan the Terrible [47]. The family name Portnyagin is derived from the nickname portnyaga (rus.- - tailor) as a designation of profession. It has been known in the Middle Ural region 
since the 17th century [46]. The basis of the family name Shkulev, researchers explain, is approximately the same as "kotomka" (rus._-purse), and metaphorically refers to miser or stingy man, etc. The family name was mentioned as common in the Arkhanglesk region according to the census of 1897 [46].

\subsection{Analysis of the Origin of Russkoustinian Lineages by Family Names Diversity}

In our study, Pomors are represented by 27 persons (43.5\%) belonging to five lineages (Shelokhovskiy, Suzdalov, Shkulev, Chikachev and Cheremkin) (Table 2). Cossacks are represented by four persons (6.5\%) of one lineage (Kiselev). We detected $37.1 \%$ of modern family names (Zashiversk), presumably originating from venturers of the Russian North and the Urals who arrived there later with the prospect of earning money from the exploration of local natural resources. Family diversity and internal division into the three colonization groups indicates the three waves of settlement of Russkoe Ust'ye.

Table 2. Groups of early and late settlers of Russkoustinians.

\begin{tabular}{|c|c|c|c|}
\hline \multicolumn{2}{|c|}{ Groups of Russkoustinians } & \multirow{2}{*}{$\begin{array}{c}\begin{array}{c}\text { Number of } \\
\text { Carriers }\end{array} \\
27 \\
\end{array}$} & \multirow{2}{*}{$\begin{array}{c}\% \\
43.5 \% \\
\end{array}$} \\
\hline Early settlers family name & "Pomors" & & \\
\hline & “Cossacks" & 4 & $6.5 \%$ \\
\hline \multirow{2}{*}{ Late settlers family name } & "Zashiversk" & 23 & $37.1 \%$ \\
\hline & Others & 8 & $12.9 \%$ \\
\hline Total & & 62 & $100 \%$ \\
\hline
\end{tabular}

\section{Discussion}

In this paper, for the first time, an analysis of family name diversity of the residents of Russkoe Ust'ye was carried out. In our study, the most common family names of the residents of Russkoe Ust'ye (Efimov, Cheremkin, Chikachev, Portnyagin, Shkulev) were brought by groups of Slavic origin. Among the most common family names, we have not found any family names of Turkic, Paleo-Asiatic, Tungusic, Semitic, Iranian, Caucasus or other origin. Moreover, our research has shown that all three groups of colonizers, identified by A.G. Chikachev, are represented among the contemporary representatives of the modern population of this small village. Based on the family name diversity, it is possible to reconstruct three possible waves of settlers' migration.

\subsection{Wave 1-“Pomors"}

According to the Russkoustinian legends, the village of Russkoe Ust'ye was founded by Russian immigrants from Velikii Novgorod, who fled from persecution by Ivan-IV the Terrible. The ancestors of the Russkoustinians crossed the Arctic Ocean on 14 kochi (rus.- - sailboats) presumably around 1570 and reached the Indigirka river delta (Figure 2). It is also possible that the ancestors of the Russkoustinians were exiled to the North, and that they moved to these places on kochi along the Arctic Ocean [22,30], but exile at that time was usually by land with a confiscation of all property. However, according to the legends, the Russkoustinians arrived on their kochi with all their household belongings including animals. From another version of their history, the Russkoustinians could have been sailors from Pomorie (territories of the modern Arkhangelsk region, North Russia), who arrived at Indigirka [47]. This hypothesis is supported by the discovery of a camp for polar sailors on the eastern coast of the Taimyr Peninsula [48]. The reasons for the moving of the Russians along the Indigirka coast may differ, but the dating of their arrival (the first quarter of the 17th century) is earlier than that of the first arrival of the Cossacks in East Siberia. The sea route was known to the North Russians-Pomors already present from the 15 th century or even earlier, at least before the spread (since the 16th century) of the kochi as a type of vessel more adapted for Arctic navigation [49]. It was more difficult, but shorter 
than the land routes and it was possible to explore not only the north of Western Siberia, but also the north of Central and Eastern Siberia. A significant colonization of the Arctic along the Northern Sea Route took place in the 16th century. On the contrary, in the 17th century the importance of the Northern Sea Route decreased and it was almost forgotten, while the Arctic and the Pacific coasts began to be discovered by the southern land routes through Siberia [50]. The results show that contemporary carriers of Pomor family names constitute $43.5 \%$ of the studied sample, which indicate the validity of the hypothesis of the Indigirka river banks settlement by natives of the Pomorye. Moreover, one of the most common family names among the modern residents of Russkoe Ust'ye-Shkulev-according to 1897 census data of the Russian Empire, was common in two provinces of the Arkhangelsk region [46].

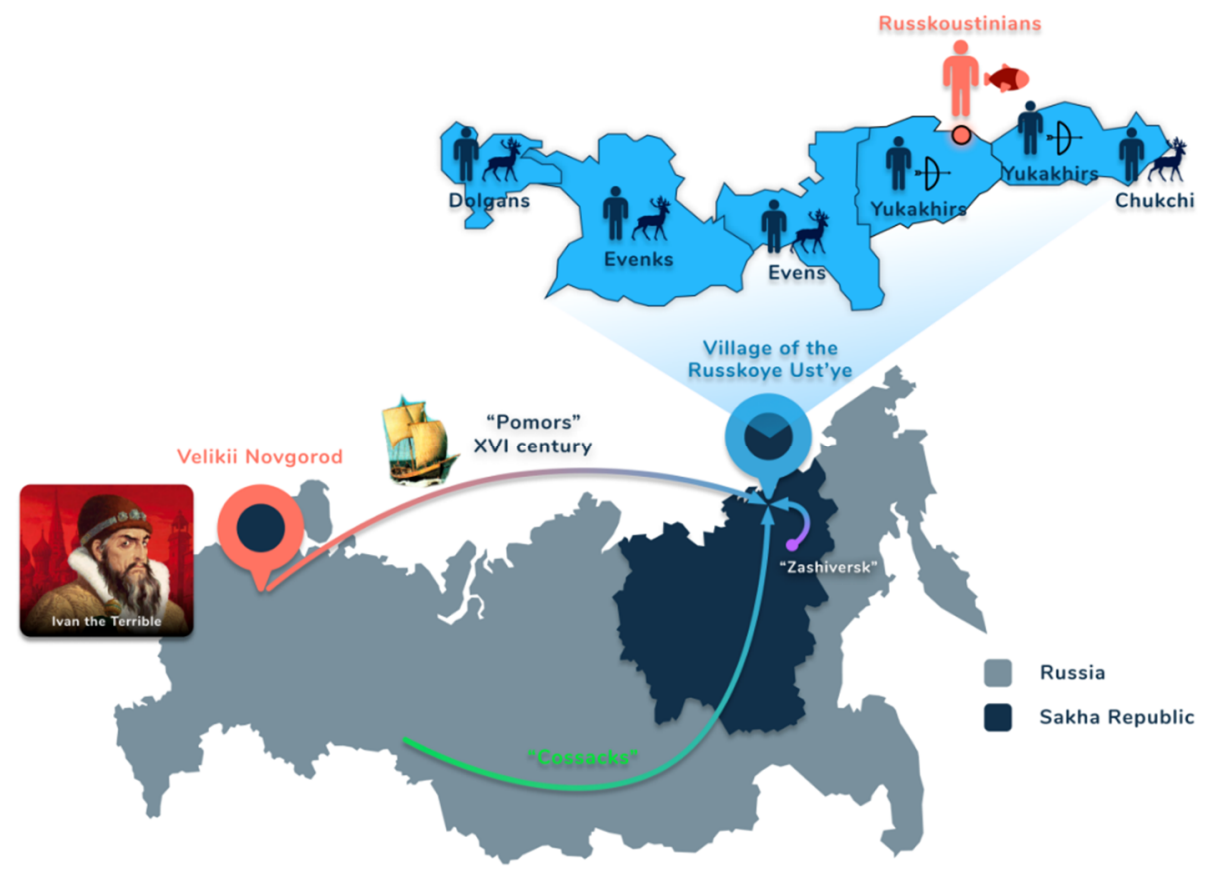

Figure 2. The supposed possible waves of settlement of Russkoe Ust'ye. Note: The "Pomors"—a hypothetical migration by Northern Sea Routes before the official Eastern Siberian colonization period (16th century). Between 1565 and 1572 Ivan the Terrible (the first Tsar of all Russia in 1547-1584) implemented the "oprichnina" - government policy with extraordinarily repressive measures in order to fight against alleged treason among the nobility. The oprichnina included the confiscation of property and lands of the nobility in favor of the government, and notorious mass executions. According to the legends, the founders of Russkoe Ust'ye were Russian immigrants (Pomors) who fled from persecution via the Arctic Ocean in around 1570 from Novgorod. The "Cossacks"—during the colonization period of the territory of Eastern Siberia by Russian explorers (mostly of Cossack origin) (17th century). The "Zashiversk" — descendants of the Zashiversk village, which was abolished in 1820 (19th century).

\subsection{Wave 2- "Cossacks"}

According to the official data, the appearance of the first Russians on the Indigirka river is associated with the expedition of Ivan Rebrov, a Cossack lieutenant from Tobol'sk (Figure 2). In August of 1638 his unit built a fortress which was later transformed into the village of Russkoe Ust'ye [27]. The first explorers who reached the banks of the Indigirka river by land from Yakutsk were the Cossacks led by Posnik Ivanov. In 1639 they founded Zashiversk. In 1820, after the abolition of Zashiversk (considerably due to a smallpox epidemic) [29], some residents migrated to Russkoe Ust'ye [27]. The village of Russkoe Ust'ye was first documented in F.P. Wrangel's expedition records from the middle of the 18th century; it was reported that it consisted of six yurts (portable dwelling), where 
lived 15 families [27]. In this study, one family name of the Cossack origin (Kiselev) was documented, belonging to four people (6.5\%). Kiselev's lineage is also considered as one of the early settlers of Russkoe Ust'ye. The presence of this family name may indicate the presence of a second wave of settlement in Russkoe Ust'ye, after the Pomors.

\subsection{Wave 3-“Zashiversk"}

The most numerous group in terms of the variety of family names, represented by 10 family names (37.1\% of carriers), is the descendants of the Zashiversk village, which was abolished in 1820, the so called "newcomers" (Figure 2). In the first years of inclusion in the borders of the Russian Empire, there was a fairly massive influx of the Russian population, interested in the abundance of fur animals and mammoth bones. Archaeologist and ethnographer E.A. Strogova, who studied the origin of the Arctic Russian population according to written sources-revision tales and registers of births-concluded that the formation of the Russian settlements on the Arctic coast of Yakutia was comprised of people mainly from the eastern regions of the Russian North and the Urals. According to the data collected from custom documents of the 1740s, hunter-trappers accounted for $90 \%$ of the total number of Russian people who migrated to the north of the Sakha Republic (lower reaches of the Lena, Indigirka, Kolyma, and Olenek rivers). Most of them came from Velikii Ustyug (24\%), and the current Vologda and Arkhangelsk regions, while Novgorodians accounted for only $1 \%$. The people arriving from Central Russia accounted for 5\%, from the western outskirts of Russia, 1\%, and other regions of Siberia, 4\% [41]. According to E.A. Strogova, immigrants from the Russian North and the Urals were the first who arrived at the lower reaches of the Indigirka river with a commercial interest in the traditional crafts of the indigenous peoples as well as in the collection of mammoth bones, and who later founded the merchant society of Russkoe Ust'ye. In this study, the common Portnyagin family name was probably brought by immigrants from Ural, since this family name is reported to be first mentioned in archive registries of that region [46].

\subsection{Evidence for the "Pomors" Version}

There is a strong possibility that there may have been second and third waves of migration, such as the modern migration. However, the first wave remains hypothetical because it is not confirmed by official documents, but the following observations of researchers testify in favor of the "Pomors" hypothesis. One of the researchers supporting the version of the Northern Sea Route was B.O. Dolgikh, who described the discovery of chess pieces and coins on the northern Faddee Island in 1940. According to the coins found on this island, these discoveries were attributed to the 1620s, before the arrival of the Cossacks [28]. A weighty argument in favor of the Pomor version of origin was recently obtained by virtue of the excellent preservation of the unique Old Russian language in the folklore of the 16th century by the people of Russkoe Ust'ye. The language and folklore of the Russkoe Ust'ye are a historical monument of Old Russian culture of the 16th and 17th centuries; some researchers even attribute it to the 15th century. The unique phenomenon of the preserved Old Russian dialect was first highlighted in literature by V.M. Zenzinov [21]. The preservation of the archaisms of the Old Russian language and folklore of the 16th century was due to conservation caused by the remoteness and isolation from the general development of Russian culture. Given the distances, geographical isolation of the northern territories, and transport accessibility, the Russkoustinians were mainly in contact with the local Yukaghir tribes, and it is noted that marriages between Russian men and Yukaghir women were frequent [1]. A mixed generation had already been formed, whose life was equally dominated by the Russian language, Orthodoxy, and Russian folklore in the middle of the 18th century. At the same time, typical for the aboriginal population of the region was the material and agricultural life of fishermen and hunters, a reverence for the spirits of nature, the heritage of life canons and mythological representations. Thus, an original Russkoustinian subpopulation was formed surrounded by the indigenous peoples of the Arctic, who called themselves "local Russians" or "old-settlers", distinguishing 
themselves from the visiting "nonlocal" Russians. The results of this study also indicate a high possibility of hypothesis for a Pomor origin of the Russkoustinians, since $43.5 \%$ of the modern analyzed family names belong to this group.

\subsection{Self-Identification and Legal Status of Russkoustinians as Minority Indigenous People of Siberia}

Expansions of the Russian first settlers and explorers reached many other landscapes of Siberia, reaching the shores of both the Arctic and Pacific oceans. It is not certain what events occurred in these lands, but they led to the formation and presence of many unique subpopulations of mixed origin who were isolated long enough to be rediscovered in later explorations. In this regard, the case of the Kamchadals has a lot in common with the Russkoustinians. The Kamchadals are officially acknowledged as indigenous minority people living in the Far East of Russia (Chukotka, Kamchatka, Magadan) who originated from the assimilation of local indigenous Siberian inhabitants and the first Russian explorers who arrived there in the late 18th century [51,52]. Genetic studies of mitochondrial DNA of the Russian old-settlers in the polar regions of Eastern Siberia showed that the majority of the maternal gene pool was represented by components of East Asian origin [34]. It is established that the majority of the mitochondrial gene pool of the Russian old-settlers (including residents of Russkoe Ust'ye) is represented by the mtDNA haplotypes specific to the indigenous inhabitants of Siberia. Thus, out of 30 haplotypes belonging to 11 haplogroups, only one lineage $(\mathrm{H} 2 \mathrm{a})$ is characteristic for the Caucasian populations and represented with a frequency of 9.4\% [34]. At the same time, the inhabitants of Russkoe Ust'ye identify themselves as "Russians" despite the high degree of cross-breeding with neighboring indigenous peoples. This ethnic identity of the Russkoustinians is mainly due to the kinship of origin, language, traditions, and culture with their ancestors although they are truly unique in every way and have all the rights to consider themselves as locals in these far lands. In previous studies, it was also noted that the Russkoustinians are people with a unique history of origin keeping in one bottle the "injection of civilization" brought to these lands by the Russian old-settlers and the "grain of originality" inherited from local ancestors [2]. However, regarding legislation it should be noted that so far in their traditional economic life, the Russkoustinians declare that they do not have the same rights as their neighbors, the Yukaghirs and the Evens. In this regard, the Russkostinians, aware of their unique cultural identity and difference from dominant Russian society, continue to fight for their inclusion on the federal list of the Indigenous small-numbered peoples of the North, Siberia and the Far East. This social justice is very important to preserve the traditional way of life in the Arctic regions and this goal completely corresponds to the United Nations' 17 Sustainable Development Goals (SDGs) aimed at achieving a decent life for all peoples on a healthy planet by 2030 [53].

\section{Conclusions}

1. In general, our research shows that most of the family names of the residents of the village of Russkoe Ust'ye located in the Arctic coast of Eastern Siberia have a Pomor origin (43.5\%). We found a smaller percentage of residents with affiliated family names of the "Cossacks" (6.5\%) and "Zashiversk" (37.1\%). This fact indicates a probability that this village was founded by Russian Pomors who arrived here via the Northern Sea Routes before the official Eastern Siberian colonization period.

2. Further molecular genetic study of the paternal Y-chromosome lineages in comparison with family name diversity will help in defining the peculiar history of their origins and will provide an additional opportunity for Russkoustinians in support of their ethnic self-identification as a separate indigenous people of Siberia.

3. Ethnic self-identification of the residents of Russkoe Ust'ye as a separate indigenous people of Siberia could help to obtain legal status for the Russkoustinians as minority indigenous people as well as support the possibility of legislative preservation of their traditional lifestyle in the territories of the settlement of their ancestors. This will contribute to the sustainable development of the Arctic in general, which be- 
comes more important considering the upcoming intensive industrial development of these regions.

Author Contributions: Conceptualization, A.V.S. and N.A.B.; formal analysis, T.V.B., A.M.C., F.M.T. and V.G.P.; investigation, G.P.R. and N.N.G.; writing—original draft preparation, A.V.S., T.V.B., G.P.R. and N.A.B.; writing-review and editing, S.E.N., O.V.V., A.N.A. and S.A.F.; supervision, S.A.F.; funding acquisition, A.V.S. and S.A.F. All authors have read and agreed to the published version of the manuscript.

Funding: This work was carried out as part of the state project of the Ministry of Science and Higher Education of the Russian Federation (FSRG-2020-0016) and the research project of the YSC CMP "Study of the genetic structure and burden of hereditary pathology in the populations of the Republic of Sakha (Yakutia)", as well as with the support of RFBR grants (No. 18-05-60035_Arctika and No. 19-34-60023_Perspektiva).

Institutional Review Board Statement: The study was conducted according to the guidelines of the Declaration of Helsinki, and approved by the local biomedical ethics committee of the Yakut Science Centre of Complex Medical Problems, Yakutsk, Russia (Protocol No.4, 1 March 2018).

Informed Consent Statement: Informed consent was obtained from all subjects involved in the study.

Data Availability Statement: The data that support the findings of this study are available from the corresponding author upon reasonable request.

Acknowledgments: The authors express their sincere gratitude to all residents of Russkoe Ust'ye who participated in this study.

Conflicts of Interest: The authors declare that there are no conflict of interests.

\section{References}

1. Pluzhnikov, N.V. Etnografiya material'noy i dukhovnoy kul'tury russkikh starozhilov Russkogo Ust'ya [Ethnography of Material and Spiritual Culture of the RussianOld-Timersin the RusskoyeUstyey]. In Russkiye Arkticheskiye Starozhily Yakutii: Sbornik Nauchnykh Statey [Russian Arctic Old-Settlers in Yakutia: A Collection of Scientific Articles]; Nikitina, S.E., Antonov, E.P., Eds.; IGIiPMNS SO RAN: Yakutsk, Russia, 2019; pp. 97-122. ISBN 978-5-902198-47-5. Available online: http://igi.ysn.ru/files/ publicasii/Russkiyearticheskiyestarozhily Yakutii.pdf (accessed on 10 August 2021).

2. Vakhtin, N.B. Russkiye Starozhily Sibiri: Sotsial'nyye i Simvolicheskiye Aspekty Samosoznaniya [Russian Old-Timers of Siberia: Social and Symbolic Aspects of Self-Consciousness]; Novoye Izdatelstvo: Moscow, Russia, 2004.

3. Law of the Republic of Sakha (Yakutia) of April 11, 2000, N 3 (167-II) “O perechne korennykh malochislennykh narodov severa i mestnostey (territoriy) ikh kompaktnogo prozhivaniya v Respublike Sakha (Yakutiya)" [On the List of Small Indigenous Peoples of the North and Areas (Territories) of Their Compact Residence in the Republic of Sakha (Yakutia)], (2000). Available online: https:/ / docs.cntd.ru/document/473510432 (accessed on 13 August 2021).

4. Resolution of the Government of the Russian Federation of 24 March 2000 N 255 "On the Unified List of Indigenous Minorities of the Russian Federation" (with Amendments and Additions of 30 September 2000; 13 October 2008; 18 May, 17 June, 2 September 2010; 26 December 2011; 25 August 2015). 2000. Available online: https://docs.cntd.ru/document/901757631 (accessed on 13 August 2021).

5. Nikitina, S.E. Russkiye arkticheskiye starozhily Respubliki Sakha (Yakutiya): Problemy sokhraneniya unikal'noy kul'tury [Russian Arctic Old-Settlers of the Republic of Sakha (Yakutia): Problems of Preserving a Unique Culture]. In Russkiye Arkticheskiye Starozhily Yakutii: Sbornik Nauchnykh Statey [Russian Arctic Old-Settlers in Yakutia: A Collection of Scientific Articles]; Nikitina, S.E., Antonov, E.P., Eds.; IGIiPMNS SO RAN: Yakutsk, Russia, 2019; pp. 16-33.

6. Crow, J.F. Surnames as biological marker. Hum. Biol. 1983, 2, 383-397.

7. Balanovskaya, Y.V.; Solov'yeva, D.S.; Balanovskiy, O.P.; Churnosov, M.I.; Sorokina, I.N.; Yevseyeva, I.V.; Abolmasov, N.N.; Pocheshkhova, E.A.; Seregin, Y.A.; Pshenichnov, A.S. "Famil'nyye portrety" pyati russkikh regionov ["Family portraits" of the five Russian regions]. Meditsinskaya Genet. 2005, 1, 2-10.

8. Balanovskaya, E.V.; Romanov, A.G.; Balanovskiǐ, O.P. Odnofamil'tsy ili rodstvenniki? Podkhody k izucheniyu svyazi mezhdu gaplogruppami y-khromosomy i familiyami [Namesakes or relatives? Approaches to investigating the relationship between $Y$ chromosome haplogroups and surnames]. Mol. Biol. 2011, 45, 473-485.

9. Nikitina, S.E. Yevropeytsy vne Yevropy: Problemy sokhraneniya kul'tury russkikh arkticheskikh starozhilov Respubliki Sakha (Yakutiya) [Europeans Outside Europe: Problems of Preserving the Culture of Russian Arctic Old-timers of the Republic of Sakha (Yakutia)]. Europe 2015, 14, 125-138. 
10. Kiseleva, N.P. Russkoust'inskiy slovar' kak element natsional'noy kul'tury [Russkoye Ustye Dictionaryas an Element of National Culture]. In Russkiye Arkticheskiye Starozhily Yakutii: Sbornik Nauchnykh Statey [Russian Arctic Old-Settlers in Yakutia: A Collection of Scientific Articles]; Nikitina, S.E., Antonov, E.P., Eds.; IGIiPMNS SO RAN: Yakutsk, Russia, 2019; pp. 202-209.

11. Charina, O.I. Russkiy fol'klor na Kolyme i Indigirke [Russian Folklore along the Kolyma and Indigirka Rivers]. In Russkiye Arkticheskiye Starozhily Yakutii: Sbornik Nauchnykh Statey [Russian Arctic Old-Settlers in Yakutia: A Collection of Scientific Articles]; Nikitina, S.E., Antonov, E.P., Eds.; IGIiPMNS SO RAN: Yakutsk, Russia, 2019; pp. 218-233.

12. Portnyagina, N.D. Ispol'zovaniye russko-ust'inskogo fol'klora na urokakh literatury [Folklore of the RusskoyeUstyein the Literature Lessons]. 2019. Available online: https://www.twirpx.org/file/3236944/ (accessed on 10 August 2021).

13. Buryak, M.K. Perspektivy vosstanovleniya narodno-pesennoy traditsii sela Russkoye Ust'ye Respubliki Sakha (Yakutiya) [The Prospects for Recovery Folk Song Tradition of the Village RusskoyeUstye of the Republic of Sakha (Yakutia)]. In Russkiye Arkticheskiye Starozhily Yakutii: Sbornik Nauchnykh Statey [Russian Arctic Old-Settlers in Yakutia: A Collection of Scientific Articles]; Nikitina, S.E., Antonov, E.P., Eds.; IGIiPMNS SO RAN: Yakutsk, Russia, 2019; pp. 257-264.

14. Berdnikova, T.A. Problema sokhraneniya narodnykh govorov kak ob"yekt yazykovoy politiki [The Problem of Conservation of National Dialects as an Object of the Language Policy]. In Russkiye Arkticheskiye Starozhily Yakutii: Sbornik Nauchnykh Statey [Russian Arctic Old-Settlers in Yakutia: A Collection of Scientific Articles]; Nikitina, S.E., Antonov, E.P., Eds.; IGIiPMNS SO RAN: Yakutsk, Russia, 2019; pp. 174-179.

15. Vasileva, R.I. Druzhinina kak issledovatel' russkikh starozhil'cheskikh govorov na territorii Yakutii [M.F. Druzhinina as a Researcher of Russian Old-Timers Dialects in Yakutia]. In Russkiye Arkticheskiye Starozhily Yakutii: Sbornik Nauchnykh Statey [Russian Arctic Old-Settlers in Yakutia: A Collection of Scientific Articles]; Nikitina, S.E., Antonov, E.P., Eds.; IGIiPMNS SO RAN: Yakutsk, Russia, 2019; pp. 184-188.

16. Chikachev, A.G. Russkiye Na Indigirke: Istoriko-Etnograficheskiy Ocherk [Russians On Indigirka: Historical And Ethnographic Essay]; Nauka. Sibirskoye Otdeleniye: Novosibirsk, Russia, 1990; pp. 23-24.

17. Vasil'yev, V.L. K voprosu o svyazyakh severnorusskikh govorov s govorom sela russkoye ust'ye na Severo-Vostoke Yakutii [On the Relationship of the Northern Russian Dialects with the Russian Ust'e in the North-East of Yakutia]. Sev. Govor. 2017, 16, 63-75.

18. Shadrin, V.I.; Nikitina, C.E. Problemi tradisionnogo ribolovstva russkih starojilov ustia reki Kolima [Problems of traditional fishing by Russian Arctic old-timers at the mouth of the Kolyma River]. In Russkiye Arkticheskiye Starozhily Yakutii: Sbornik Nauchnykh Statey [Russian Arctic Old-Settlers in Yakutia: A Collection of Scientific Articles]; Nikitina, S.E., Antonov, E.P., Eds.; IGIiPMNS SO RAN: Yakutsk, Russia, 2019; pp. 33-43.

19. Zhukova, L.N.; Neizvestnaya zapiska, D.D. Travina o khozyaystve i byte russkoust'intsev [D.TravinUnpublished Note on the Economy and Life of RusskoyeUstye locals]. In Russkiye Arkticheskiye Starozhily Yakutii: Sbornik Nauchnykh Statey [Russian Arctic Old-Settlers in Yakutia: A Collection of Scientific Articles]; Nikitina, S.E., Antonov, E.P., Eds.; IGIiPMNS SO RAN: Yakutsk, Russia, 2019; pp. 65-67.

20. Boyakova, S.I. Pravovoy status i etnicheskaya identichnost' russkikh arkticheskikh starozhilov Yakutii [Legal status and ethnic identity of Russian Arctic old-timers of Yakutia], Arctic XXI century. Humanities 2016, 4, 151.

21. Zenzinov, V.M. Starinnyye Lyudi u Kholodnogo okeana. Russkoye ust'ye Yakutskoy Oblasti Verkhoyanskago Okruga [Old People near the Kholodny Ocean. Russkoe Ustye, Yakutsk Region, Verkhoyanskiy District]; Tipografiya, P.P., Ed.; Ryabushinskago: Moscow, Russia, 1914.

22. Skvortsov, E.F. V Pribrezhnykh Tundrakh Yakutii [In the Coastal Tundra of Yakutia]; Trudy Komissii po Izucheniyu Yakutskoy ASSR: Leningrad, USSR, 1930; p. 15.

23. Strogova, E.A. Etnograficheskiye i arkheologicheskiye issledovaniya russkikh arkticheskikh starozhilov Yakutii [Ethnographic and archaeological studies of Russian Arctic old-timers of Yakutia]. Bull. Omsk. Univ. 2017, 3, 156-160.

24. Belov, M.I. Istoriya otkrytiya Severnogo morskogo puti. V 4 tomakh. Arkticheskoye moreplavaniye s drevneyshikh vremen do serediny XIX veka History of the discovery of the Northern Sea Route. In 4 Volumes. Arctic Navigation from Ancient Times to the Middle of the 19th Century; Maritime Transport: Moscow, Russia, 1956; p. 1.

25. Birkenhof, A.L. Potomki Zemleprokhodtsev. Vospominaniya-Ocherki o Russkikh Porechanakh Nizov'yev i del'ty Reki Indigirki [Descendants of the Pathfinders. Memoirs and Essays about Russian Porechans of the Lower Reaches and Delta of the Indigirka River]; Mysl: Moscow, Russia, 1972.

26. Gurvich, I.S. Russkiye na severo-vostoke Sibiri v XVII veke [Russians in the North-East of Siberia in the 17th century]. Proc. Inst. Ethnol. 1964, 84, 71-91.

27. Alekseyev, A.N. Pervyye Russkiye Poseleniya XVII-XVIII vv. na Severo-Vostoke Yakutii [First Russian Settlements of the XVII-XVIII Centuries in North-East Yakutia], Seriya Istoriya i kul'tura Vostoka Azii; Izd-vo Instituta arkheologii i etnografii SO RAN: Novosibirsk, Russia, 1996; p. 152.

28. Dolgikh, B.O. Novyye dannyye o plavanii russkikh severnym morskim putem $v$ XVII veke [New data on the navigation of the Russian Northern Sea Route in the XVII century]. Probl. Arktiki 1943, 2, 195-227.

29. Okladnikov, A.P.; Gogolev, Z.V.; Ashchepkov, Y.A. Dreoniy Zashiversk. Dreonerusskiy Zapolyarnyy Gorod [Ancient Zashiversk. Ancient Russian Zapolarny Town]; Nauka: Moscow, Russia, 1977; p. 34.

30. Skvortsov, E.F. Russkiye na Indigirke [Russians on the Indigirka River]. Topogr. Geod. Zhurnal 1910, 11, 70-166.

31. Osipova, O.V.; Maklashova, E.G. Identichnocti molodeji v Arktike [The Identities of Arctic Youth]. Sociol. Res. 2015, 5, 139-144. 
32. Antonov, E.P. Sovremennoye samosoznaniye russkikh starozhilov Pokhodska v kontekste ekonomicheskoy i sotsiokul'turnoy transformatsii [Modern Identity of Russian Old-Timers of Pokhodsk in the Context of Economic and Sociocultural Transformation]. In Russkiye Arkticheskiye Starozhily Yakutii: Sbornik Nauchnykh Statey [Russian Arctic Old-Settlers in Yakutia: A Collection of Scientific Articles]; Nikitina, S.E., Antonov, E.P., Eds.; IGIiPMNS SO RAN: Yakutsk, Russia, 2019; pp. 44-50.

33. Aksyanova, G.A. Russkoye Ustye: Anthropological study. Archaeol. Ethnol. Anthropol. Eurasia 2015, 43, 142-155. [CrossRef]

34. Sukernik, R.I.; Volod'ko, N.V.; Mazunin, I.O.; El'tsov, N.P.; Starikovskaia, E.B. Geneticheskaya istoriya russkikh starozhilov polyarnogo severa Vostochnoy Sibiri po rezul'tatam analiza izmenchivosti mtDNK [The genetic history of long-term Russian resident populations of polar northeastern Siberia based on mitochondrial DNA variability]. Genetika 2010, 46, 1571-1579. [PubMed]

35. Zei, G.; Guglielmino, C.R.; Siri, E.; Moroni, A.; Cavalli-Sforza, L.L. Surnames as neutral alleles: Observations in Sardinia. Hum. Biol. 1983, 55, 357-365. [PubMed]

36. Kucher, A.N.; Danilova, A.L.; Koneva, L.A.; Nogovitsina, A.N. Populyatsionnaya struktura sel'skikh naselennykh punktov Respubliki Sakha (Yakutiya): Famil'naya struktura [Population structure of rural settlements of the Republic of Sakha (Yakutia): Family structure]. Genetika 2007, 43, 818-826. [PubMed]

37. Revazov, A.A.; Paradeyeva, G.M.; Yel'chinova, G.I. Prigodnost' russkikh familiy v kachestve “kvazigeneticheskogo" markera [The suitability of Russian surnames as a "quasi-genetic" marker]. Genetika 1986, 22, 699-703. [PubMed]

38. Pettener, D.; Pastor, S.; Tarazona-Santos, E. Surnames and genetic structure of a high-altitude Quechua community from the Ichu River Valley, Peruvian Central Andes, 1825-1914. Hum. Biol. 1998, 70, 865-887. [PubMed]

39. Kucher, A.N.; Tadinova, V.N.; Puzyrev, V.P. Genetiko-demograficheskaya kharakteristika sel'skikh populyatsiy Respubliki Altay: Polovozrastnoy sostav, famil'naya i rodovaya struktura [Genetic and demographic characteristics of rural populations in the Altai Republic: Age and sex composition, family and clan structure]. Genetika 2005, 41, 254-260. [PubMed]

40. Kalmykova, Y.N.; Malovichko, S.I. Istoriya proiskhozhdeniya russkikh family [The history of the origin of Russian surnames]. In Sbornik Nauchnykh Statey po Itogam Mezhdunarodnogo Nauchnogo Festivalya Molodozhnogo Proyektirovaniya-2020 [Collection of Scientific Articles Following the Results of the International Scientific Festival of Youth Design-2020]; Starykh, L.V., Zelenkova, T.V., Yakovlev, M.V., Kotova, Y.G., Zaval'tseva, O.A., Khanina, M.A., Silenko, V.Y., Sokol'skaya, L.V., Babayeva, Y.V., Kamenskikh, N.A., Eds.; Redaktsionno-Izdatel'skiy Otdel GGTU: Orekhovo-Zuyevo, Russia, 2020; pp. 200-205. ISBN 978-5-87471-368-3. Available online: https://www.ggtu.ru/doc_word/nauch_rabota/2020-2021/sbornik_nauch_statey_2020.pdf (accessed on 13 September 2021).

41. Strogova, E.A. Formirovaniye postoyannogo russkogo naseleniya i obrazovaniye etnicheskoy territorii na severe Yakutii v XVII-XVIII vv. [The Establishment of the Permanent Russian Population and Formation of Ethnic Territory in the North of Yakutia in the XVII-XVIII Centuries]. In Russkiye Arkticheskiye Starozhily YAKUTII: Sbornik Nauchnykh Statey [Russian Arctic Old-Settlers in Yakutia: A Collection of Scientific Articles]; Nikitina, S.E., Antonov, E.P., Eds.; IGIiPMNS SO RAN: Yakutsk, Russia, 2019; pp. 7-15.

42. Ganzhina, I.M. Slovar' Sovremennykh Russkikh Familiy [Dictionary of Modern Russian Surnames]; AST: Moscow, Russia, 2001; ISBN 5-237-04101-9.

43. Vedina, T.F. Entsiklopediya Russkikh Familiy. Tayny Proiskhozhdeniya i Znacheniya [Encyclopedia of Russian Surnames. Secrets of Origin and Meaning]; AST: Moscow, Russia, 2008; ISBN 978-5-271-17927-3.

44. Fedosyuk, Y.A. Russkiye Familii: Populyarnyy Etimologicheskiy Slovar' [Russian Surnames: A Popular Etymological Dictionary]; Detskaya Literature: Moscow, Russia, 1972.

45. Khigir, B.Y. Entsiklopediya Russkikh Family [Encyclopedia of Russian Surnames]; AST: Moscow, Russia, 2006.

46. Mosin, A.G. Slovar' Ural'skikh family: Materialy Dlya Slovarya. Familii Zhiteley Kamyshlovskogo Uyezda Permskoy Gubernii (na Materialakh Ispovednykh Rospisey 1822 goda) [Dictionary of the Ural Surnames: Surnames of the Residents of the Kamyshlovsky District of the Perm Province (Based on the Materials of Confessional Paintings of 1822)]; Russian Academy of Sciences: Yekaterinburg, Russia, 2000.

47. Shub, T.A. Drevnerusskoye Naseleniye Nizoviy Reki INDIGIRKI [Ancient Russian Population of the Lower Indigirka River]; Doklady na Vtorom Vsesoyuznom Geograficheskom s"yezde: Moscow, Russia, 1949.

48. Okladnikov, A.P. Russkiye Polyarnyye Moryaki XVII veka u Beregov Taymyra [Russian Polar Seafarers of the 17th Century off the Coast of Taimyr]; Izd-vo i tip. Glavsevmorputi: Moscow, Russia, 1948.

49. Khelimskiy, Y.A. Komparativistika, Uralistika: Lektsii i stat'i [Comparativism, Uralistics: Lectures and Articles]; Yazyki Russkoy kul'tury: Moscow, Russia, 2000; pp. 351-352.

50. D'yachenko, V.I. Puti i Osobennosti Kolonizatsii Russkimi Taymyra [Ways and Peculiarities of Russian Colonisation of the Taymir]; Sbornik Nauchnykh Statey: Sibir'v Kontekste Russkoy Modeli Kolonizatsii (XVII—nachalo XX v.); MAE RAN: St. Peterburg, Russia, 2014; pp. 68-123.

51. Murashko, O.A. Itel'meny i Kamchadaly: Metamorfozy Etnicheskoy Identichnosti [The Itelmen and the Kamchadars: Metamorphosis of Ethnic Identity]; Gumanitarnaya Nauka v Rossii: Sorosovskiye Laureaty. ISTORIYA. Arkheologiya; Kul'turnaya Antropologiya i Etnografiya: Moscow, Russia, 1996; p. 358. 
52. Khakhovskaya, L.N. Kamchadaly Magadanskoy Oblasti (Istoriya, kul'tura, Identifikatsiya) [Kamchadals of Magadan Oblast (History, Culture, Identification)]; SVKNII DVO RAN: Magadan, Russia, 2003.

53. Lee, B.X.; Kjaerulf, F.; Turner, S.; Cohen, L.; Donnelly, P.D.; Muggah, R.; Davis, R.; Realini, A.; Kieselbach, B.; MacGregor, L.S.; et al. Transforming Our World: Implementing the 2030 Agenda Through Sustainable Development Goal Indicators. J. Public Health Policy 2016, 37 (Suppl. 1), 13-31. [CrossRef] [PubMed] 